\title{
Influence of Various Types of Waste on the Main Properties of Gypsum Based Composites for Thermal Insulations
}

\begin{abstract}
CRISTINA DIMA, ALINA BADANOIU*, STEFANIA STOLERIU, DIANA LUCA
University Politehnica of Bucharest, Faculty of Applied Chemistry and Materials Science, 1-6 Ghe. Polizu Str., 011061, Bucharest, Romania

In the last decade numerous research studies were performed in the attempt to recycle several types of industrial waste. This study has as main objective the obtaining and characterization of gypsum based composite materials with various amounts of industrial wastes (flue gas desulfurization gypsum and recycled rubber). The main properties assessed for these materials were setting time, compressive strength, apparent density and thermal conductivity. The gypsum binder was partially replaced with thermally treated flue gas desulfurization gypsum (FGDgp t) without an important negative impact on the compressive strength; if the replacement amount is up to 40 wt.\% the resulted binder still meets the requirements imposed for this property by specific norm for gypsum plaster - EN 13279-1. The substitution of gypsum plaster with FGDgp $t$ shortens the setting time, therefore it was compulsory to use also sodium citrate as retarder addition. The addition of 5 wt.\% rubber waste has a positive effect on the thermal conductivity of composite materials based on gypsum binder with/without FGDgp t. Consequently, these materials could be used for the manufacture of low cost, eco-friendly thermal insulation materials.
\end{abstract}

Keywords: flue gas desulfurization gypsum, recycled rubber, industrial waste, thermal conductivity

Raising living standards and technological development accelerate the consumption and rapid degradation of renewable natural resources, while increasing volumes of waste. The accumulation of large amounts of industrial waste causes numerous environmental problems and high costs for their neutralization. In these circumstances, manufacturers must identify and implement new measures to move towards a circular economy industry.

Thus, rubber wastes resulted from the automotive industry (tires or other rubber auxiliary components) cannot be recycled entirely through vulcanization processes. These types of wastes are not easily biodegradable and become a problem for the environment.

Several studies focused on the use of rubber waste as filler in concrete and mortar [1-3]. The obtained materials present improved flexibility, thermal and acoustic properties.

Correia et al. [1] studied the effect of rubber additions on the compressive strength of mortar mixtures. The natural aggregate was replaced by a maximum of $30 \%$ rubber waste, and the compressive strength after 28 days was 12-15 $\mathrm{MPa}$ representing $50-83 \%$ from the compressive strength of mortar prepared with natural aggregate [1] .

Topcu and Demir [2] assessed the durability of concrete and mortar with addition of rubber waste and concluded that this type of waste should be used mainly in concrete destinated to be used in less harsh environmental conditions.

The incorporation of recycled rubber particles in a gypsum matrix was less studied. Herero et al. [3] studied the influence of rubber waste dosage and particle size on the mechanical, thermal and acoustic properties of mortars based on plaster with rubber additions. The best thermal and acoustical properties were obtained for the composites with the small size rubber particles $(<0.6 \mathrm{~mm})$.

Another environmental problem is raised by industrial wastes generated in electrical power plants such as fly ash or flue gas desulfurization gypsum. Up to now, numerous studies reported various valorization methods of fly ash in the building materials industryi.e. manufacture of portland cement (as alternative raw material or admixture), manufacture of concrete or geopolymers [49].

Flue gas desulfurization gypsum (FGD gypsum), waste generated in the desulfurization process of gases generated in power plants, raises also many environmental issues [10]. Several studies reported that FGD can be used in cement industry to replace natural gypsum as setting retarder [11] or for the total or partial replace of natural gypsum in the manufacture process of gypsum plaster [12].

In this context, this paper presents a new method to valorize FGD i.e. the use of FGD gypsum and recycled rubber for the manufacture of thermal insulation materials.

\section{Experimental part \\ Materials}

The materials used in this study were:

- gypsum plaster $(G)$ for building purposes in conformity with EN 13279-1, with the main properties presented in table 1 [13];

- flue gas desulfurization gypsum (FGD) resulted from the desulfurization process of the combustion gases in a Romanian power plant; the main characteristics of FGD, according to the producer, are presented in table 2 . In order to improve the binding properties of FGD gypsum, this waste was thermally treated at $120^{\circ} \mathrm{C}$ (FGDgp t).

- waste rubber particles $(R)$ from recycling of scrap tires, with a grain sizes comprised between 4-6 $\mathrm{mm}$.

Table 1

MAIN CHARACTERISTICS OF GYPSUM PLASTER

\begin{tabular}{|l|c|}
\hline Characteristics & SR EN 13279 \\
\hline Reaction to fire & Class A1 \\
\hline Fineness & $99 \%$ under $315 \mu \mathrm{m}$ \\
\hline Content of calcium sulfate & $>50 \mathrm{w} \%$ \\
\hline Initial setting time & $10-15 \mathrm{~min}$ \\
\hline
\end{tabular}

* email: alina.badanoiu@upb.ro, Phone: 0214023884 
Table 2

CHEMICAL COMPOSITION OF FGD GYPSUM

\begin{tabular}{|c|c|c|c|}
\hline Component & $w t \%$ & Component & $w t \%$ \\
\hline Chloride & 5.95 & Potassium & 0.83 \\
\hline Fluoride & 0.34 & Aluminum & 0.009 \\
\hline Sulphate & 65.70 & Iron & 0.002 \\
\hline Calcium & 16.51 & Manganese & 0.003 \\
\hline Magnesium & 7.64 & Zinc & 0.006 \\
\hline Sodium & 2.76 & Total organic carbon & 0.25 \\
\hline
\end{tabular}

\section{Mixtures design}

DesignExpert $®$ software [14] was used to establish compositions based on the above mentioned three components (G, FGDgp t and R), with: i) adequate mechanical strengths after 7 days of hardening, and ii) small values of apparent density required to provide good thermal insulation properties.

This software designed (generated) 16 mixtures. Three points were replicated: two of them in the corners and one on the side of the triangle; these replications are designed to identify and quantify experimental errors. Moreover, in the design of mixtures, the maximum rubber content was limited to $50 \%$ wt

For the experimental program two main properties of these composites were selected:

- compressive strength of mixtures prepared with water to binder ratio of 0.5 , assessed after 7 days of hardening;

- apparent (geometrical) density, assessed on mixtures hardened for 7 days.

The raw materials ( $G$, FGDgp $t$ and $R$ ) were homogenized in dry state and subsequently mixed with water in a Hobart mixer. These compositions were cast in two types of moulds i.e. cubes $(20 \times 20 \times 20 \mathrm{~mm})$ and panels $(300 \times 300 \times 10 \mathrm{~mm})$. The hardening was performed in air at $20+2^{\circ} \mathrm{C}$.

\section{Methods}

The mineralogical compositions of FGD and FGDgp $t$ were assessed by X-ray diffractions (XRD). The XRD patterns were obtained using a monochromatic CuK $\alpha$ radiation $(\lambda=1.5406 \AA)$, range $2 \Theta$ from 10 to $60^{\circ}$.

Setting time and compressive strength of gypsum binder with/without FGDgp $t$ addition were determined in conformity with the methods presented in European Standard for gypsum binders and gypsum plasters [15].

Thermal conductivity $(\lambda)$ was determined with an HESTO-Lambda-CONTROL A90-equipment; this equipment measures the heat flow through a specimen placed between two plates with different temperatures; the measurement accuracy is $\pm 3 \%$ in accordance with EN 12667 [16].

\section{Results and discussions}

\section{Materials characterization}

The mineralogical compounds identified by $X$-ray diffraction analysis (XRD) in FGD gypsum (fig. 1) are: calcium sulphate dihydrate $\left(\mathrm{CaSO}_{4}, 2 \mathrm{H}_{2} \mathrm{O}\right)$ and calcium sulphite hemihydrate $\left(\mathrm{CaSO}_{3} \cdot 0.5 \mathrm{H}_{2} \mathrm{O}\right)[17,18]$.

After thermal treatment at $120^{\circ} \mathrm{C}$ of FGD gypsum, XRD patterns shows the presence of calcium sulphate hemihydrate $\left(\mathrm{CaSO}_{4} \cdot 0.5 \mathrm{H}_{2} \mathrm{O}\right)$ resulted by the partial dehydration of calcium sulphate dihydrate $\left(\mathrm{CaSO}_{4} \cdot 2 \mathrm{H}_{2} \mathrm{O}\right)$ (fig.1).
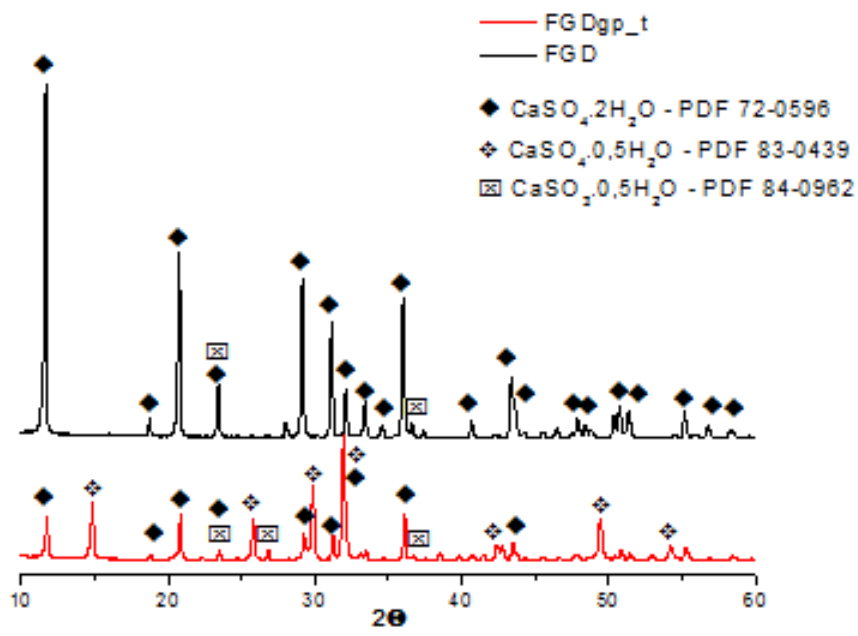

Fig.1. XRD patterns of FGD gypsum (FGD) and FGD gypsum after thermal treatment (FGDgp_t)

The values of compressive strength assessed after 7 days of hardening, on the designed 16 mixtures, were introduced in the software. For this property was chosen the Quadratic model (for which the standard deviation has the smallest value) and 97 solutions have resulted; these solutions were graphically processed as iso-property curves (contour plots) (fig.2a). In this model the correlation between experimental and calculated values is satisfactory (fig. 2b).

As it can be seen from figure 2, the compressive strengths assessed on these composites are comprised between 1.2 and $10 \mathrm{MPa}$, the lower values being recorded for the compositions in which gypsums is replaced by FGDgp $t$ (up to $25 \mathrm{wt} . \%$ ) and the rubber dosage increase (up $25 \mathrm{w} t . \%$ ); ithas to be noted that the increase of rubber content over $25 \mathrm{wt} \%$ led to no recordable compressive strength values for all mixtures.

For the apparent density, the model chosen was linear and contour plots are presented in figure 3 a. The values of apparent density are comprised between $0.96 \mathrm{~g} / \mathrm{cm}^{3}$ (for the compositions with higher dosage of rubber $-50 \%$ ) and $1.5 \mathrm{~g} / \mathrm{cm}^{3}$ for the compositions with a higher amount of FGDgp t.

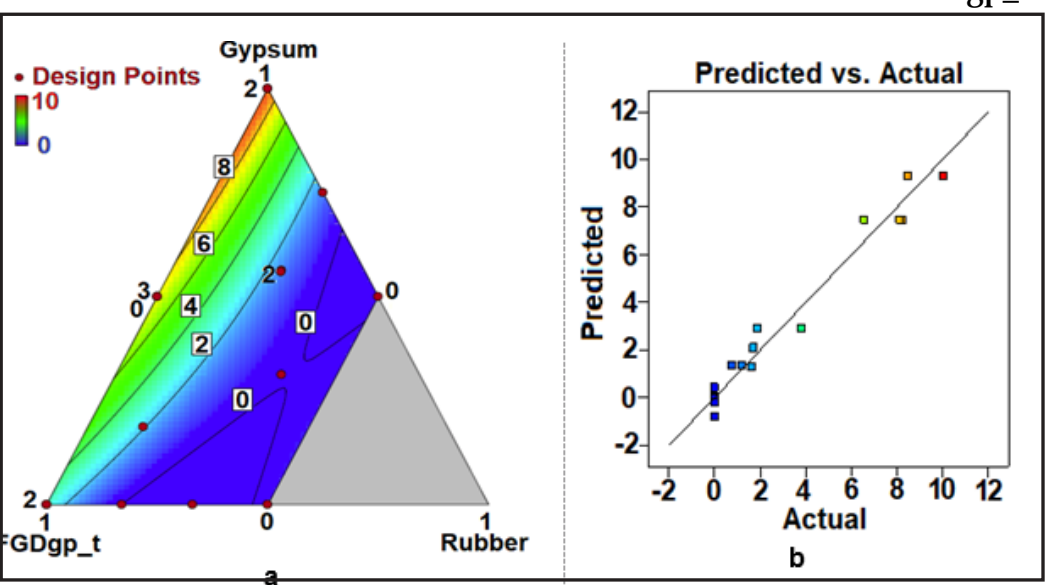

Fig. 2. Compressive strength: a) contour plots for compressive strength assessed on composite materials hardened for 7 days;

b) correlation between experimental and calculated compressive strength values 


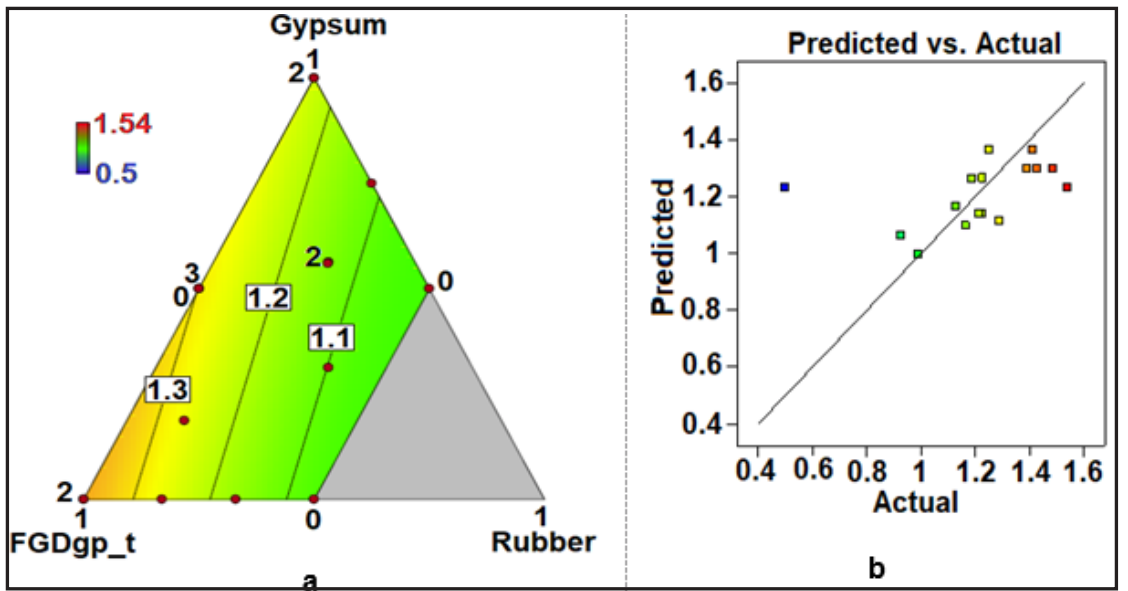

Fig.3. Apparent (geometric) density: a) contour plots for apparent density assessed on composite materials hardened for 7 days; $b$ ) correlation between experimental and calculated density values
However, the correlation factor between calculated and experimental values (fig. $3 \mathrm{~b}$ ) is much smaller and is primarily due to the experimental errors, explainable when the geometrical density is assessed (a less accurate method as compared for example with helium pycnometer method).

Based on the data provided by these two models, it was selected a ternary composition (X) which comply with the requirement for compressive strength of gypsum binders. (i.e. higher than $2 \mathrm{MPa}$ ) [19] and has also a low value of apparent (geometric) density - below $1.3 \mathrm{~g} / \mathrm{cm}^{3}$. The selected composition ( $\mathrm{X}$ ) contains $47 \mathrm{wt}$.\% gypsum plaster (G), 48 wt.\% FGDgp t and 5 wt.\% rubber waste (R).

The compressive strength values assessed after 2 and 7 days of hardening and the apparent density of material with composition $\mathrm{X}$ are presented in table 3 .

Another important property, for this type of composite materials based on gypsum binder, is the setting time (European Standard EN 13279-1 [19]). Thus, the setting time was determined for the composition without rubber waste corresponding to the composition $X$ - hereafter referred to as $\mathrm{X}_{1}$ (table 4).

The final setting time ( $6 \mathrm{~min}$ ) assessed for this composition is too short as compared with the final setting time imposed by standard i.e. minimum 20 min [19]. Therefore, it is necessary to use also a retarder addition. Based on the results reported by Muller et al. [20] and
Camarini etal. [21], sodium citrate was chosen to be used as retarder. The setting times, assessed on pastes with various amounts of sodium citrate (calculated with reference to G+FGDgp t mixture), are presented also in table 4.

As it can be seen from the data presented in table 4, the increase of sodium citrate dosage determines, as expected, a delay of initial and final setting times. The composition with $0.08 \%$ sodium citrate, which has a final setting time of $20 \mathrm{~min}$, complies with the conditions stipulated in EN 13279-1 norm and is considered adequate. Although the composition with $0.2 \mathrm{wt} \%$ sodium citrate meets also the requirements of this norm, it was not selected due to the important delay of initial setting time which most probably has a negative influence on the mechanical strength values after short periods of time ( 2 h).

For the composition with $0.08 \mathrm{wt} \%$ sodium citrate it has been verified how this retarding additive influences the compressive strength values at different curing times and in parallel was studied the impact of rubber waste addition on the compressive strength. The results are presented in table 5 .

As it can be seen from table 5 , the addition of rubber waste (compositions $X$ and $X+0.08 w t . \%$ sodium citrate) decreases the mechanical strength of this type of composite materials. The rubber particles have a porous

\begin{tabular}{|l|c|c|}
\hline \multicolumn{1}{|c|}{ Properties/UM } & Experimental & Predicted \\
\hline Compressive strength after 2 hours/ (MPa) & 2.27 & - \\
\hline Compressive strength after 7 days/ (MPa) & 4 & $4.73 \pm 0.38$ \\
& 1.4 & $1.27 \pm 0.074$ \\
\hline
\end{tabular}

Table 3

EXPERIMENTAL AND PREDICTED PROPERTIES OF MATERIAL WITH COMPOSITION X

\begin{tabular}{|l|c|c|}
\hline \multirow{2}{*}{ Binders } & \multicolumn{2}{|c|}{$\begin{array}{c}\text { Setting time/ } \\
\text { min }\end{array}$} \\
\cline { 2 - 3 } & initial & final \\
\hline $\mathrm{X}_{1}$ & 4 & 6 \\
\hline $\mathrm{X}_{1}+0.04$ wt. \% sodium citrate & 8 & 11 \\
\hline $\mathrm{X}_{1}+0.08$ wt.\% sodium citrate & 14 & 20 \\
\hline $\mathrm{X}_{1}+0.2$ wt.\% sodium citrate & 45 & 52 \\
\hline
\end{tabular}

Table 4

SETTING TIME FOR THE COMPOSITION X (WITHOUT WASTE RUBBER)

\begin{tabular}{|l|c|c|}
\hline \multirow{2}{*}{ Compositions } & \multicolumn{2}{|c|}{$\begin{array}{c}\text { Compressive strength } \\
\text { (MPa) after: }\end{array}$} \\
\cline { 2 - 3 } & $2 \mathrm{~h}$ & 7 days \\
\hline $\mathrm{X}_{1}+0.08$ wt. \% sodium citrate & 2.65 & 4.62 \\
\hline $\mathrm{X}$ & 2.27 & 4.00 \\
\hline $\mathrm{X}+0.08$ wt. \% sodium citrate & 1.75 & 3.5 \\
\hline
\end{tabular}

Table 5

COMPRESSIVE STRENGTHS OF THE COMPOSITIONS BASED ON GYPSUM PLASTER AND FGDgp_t 


\begin{tabular}{|l|c|}
\hline \multicolumn{1}{|c|}{ Composition } & $\begin{array}{c}\text { Thermal conductivity } 10^{\circ} \mathrm{C} \\
(\mathrm{W} / \mathrm{m} . \mathrm{K})\end{array}$ \\
\hline $\mathrm{G}+5 \mathrm{wt} \% \mathrm{R}$ & 0.157 \\
\hline $\mathrm{X}+0.08 \%$ sodium citrate & 0.206 \\
\hline
\end{tabular}

Table 6

THERMAL CONDUCTIVITY OF THE COMPOSITE MATERIALS BASED ON GYPSUM PLASTER ASSESSED AFTER 7 DAYS OF HARDENING

surface therefore water can be partially adsorbed causing a decrease of workability of fresh paste; this decrease of workability will determine the decrease of compressive strengths. These results are in good agreement with those obtained in previous research works on gypsum plaster with waste rubber content [3].

The values of thermal conductivity assessed on the designed compositions based on gypsum binder are presented in table 6.

The thermal conductivity of the composites based on gypsum plaster $(\mathrm{G})$ with 5 wt.\% rubber $(\mathrm{R})$ content has a thermal conductivity of $0.157 \mathrm{~W} / \mathrm{m} . \mathrm{K}$, lower as compared with the thermal conductivity reported in literature for gypsum plaster panels i.e. $0.276-0.4 \mathrm{~W} / \mathrm{m} . \mathrm{K}[21,22]$. The thermal conductivity measured for the composition $X$ with 0.08 wt \% sodium citrate is slightly higher as compared with the composition based on gypsum plaster but is smaller as compared with the thermal conductivity of FGD gypsum $(0.47+10 \% \mathrm{~W} / \mathrm{m} . \mathrm{K})$ reported by Tesarek et al. [22]. The decrease of thermal conductivity in the composition with rubber content was to be expected due to the increase of void space between rubber particles and binder matrix [1].

\section{Conclusions}

The results presented in this paper highlight the possibility to valorize two types of industrial wastes (i.e. FGD gypsum generated in electrical power plant and the rubber waste from scrap tires) in the production of building materials with good thermal properties.

Considering these experimental results, the following conclusions can be drawn:

- The gypsum plaster can be partially replaced with thermally treated flue gas desulfurization gypsum (FGDgp_t) without an important negative impact on the compressive strength; if the replacement amount is up to 40 wt. \% the resulted binder still meets the requirements imposed for this property by specific norm for gypsum plaster- EN 13279-1.

- The setting time of gypsum binder with FGDgp_ $t$ content is too short (below 20 min - the minimum value stipulated in European Standard EN 13279-1) therefore it was necessary to use also a retarder i.e. sodium citrate (0.08 wt. \% with reference to binder).

- The addition of small amount of rubber waste ( $5 \mathrm{wt} . \%$ ) has a positive effect on the thermal properties of composite materials based on gypsum plaster with/withoutFGDgp_t.

\section{References}

1. CORREIA S.L., PARTALA T., LOCH F.C, SEGADAES A.M., Compos. Struct. 92, Nr. 9, 2010, p. 2047.

2. TOPCU IB, DEMIR A., J Mater Civil Eng. 19, Nr. 2, 2007, p. 173.

3. HERRERO S., MAYOR P., HERNANDEZ-OLIVARES F., Mater. Des. 47, 2013, p. 633.

4. RASHAD A.M., Int. J. Sust. Built. Environ. 4, Nr. 2, 2015, p. 278.

5. HEMALATHA T., RAMASWAMY A., J. Clean. Prod., 147, 2017, p. 546. 6. TORRES-CARRASCO M., PUERTAS F., Rev. Rom. Mat. 47, Nr. 1, 2017, p. 3

7. WACHTER, M.R., IONEL, I., NEGREA, A., CEBRUCEAN, D., MANZATU, V., CIOPEC, M.,Rev. Chim. (Bucharest), 66, no. 11, 2015, p. 1881

8. CHENDES, R., BOB, C., BADEA, C., PODOLEANU, C.E., DAN, S., IURES, L.,Rev. Chim. (Bucharest), 67, no. 9, 2016, p. 1868

9. IBRAHIM W.M.W, HUSSIN K., AL BAKRI ABDULLAH M.M., KADIR A.A. DERAMAN L.M., SANDU A.V., Rev. Chim. (Bucharest), 68, no. 9, 2017, p. 1978

10. CÓRDOBA P., Fuel 144, 2015, p. 274.

11. CAILLAHUA M.C., MOURA F.J ., J. Mater. Res. Technol. 2017, http:/ /dx.doi.org/10.1016/j.jmrt.2017.08.005, ARTICLE IN PRESS

12. LEI D.Y., GUO L.P., SUN W., LIU J., MIAO C., Constr. Build. Mater. 153, 2017, p. 765

13.*** Technical Data Sheet - Rigips $®$ Model Gips, Rigips Saint - Gobain [Internet] 2017. Available from http://www.rigips.ro/sites/default/files/ Fisa_Tehnica_RIGIPS_Model_Gips_ipsos_alb_modelaj_stucaturi_ 2016 - 04 20.pdf (in romanian).

14.*** DesignExpert ${ }^{*}$ Software [Internet] 2017. Available from http:// www.statease.com /dx10.html.

15. *** European Standard EN 13279-2. Gypsum binders and gypsum plasters. Part 2: Test methods

16. *** European Standard EN 12667. Thermal performance of building materials and products - Determination of thermal resistance by means of guarded hot plate and heat flow meter methods - Products of high and medium thermal resistancee

17. GALOS K.A., SMAKOWSKI T.S, SZLUGAJ . J., Appl. Energ., 75, 2003, p. 257.

18. ROWE G., 2012. Available from http://www.chemicalprocessing. com/assets/ wp_downloads/pdf/AZI-w hite-paper-LOD-vs-thermo gravimetric-analysis.pdf

19.*** European Standard EN 13279-1. Gypsum binders and gypsum plasters. Part 1: Definitions and requirements

20. MUELLER M., FISCHER H.B., BORGARDT N., SOLOVEV S., SHLONKINA S., GARKAWI M.S., 2007. Available from http:// leidykla.vgtu.It/conferences/ MBM_2007/1pdf /Mueller_naujas.pdf 21. CAMARINI G., CAVALINI PINTO M.C, GOULART De MOURA A., REGGIANI MANZO N., Constr. Build. Mater. 124, 2016, p. 383.

22. TESAREK P., DRCHALOVA J, KOLISKO J ., ROVNANIKOVA P., CERNY R., Constr. Build. Mater. 21, 2007, p. 1500.

Manuscript received: 17.01 .2018 